\title{
The role of environmental factors in the induction of oxidative stress in zebra mussel (Dreissena polymorpha)
}

\author{
Adrianna Wojtal-Frankiewicz • Joanna Bernasińska • Piotr Frankiewicz • \\ Krzysztof Gwoździński • Tomasz Jurczak
}

Received: 19 December 2016/ Accepted: 22 March 2017/Published online: 29 March 2017

(C) The Author(s) 2017. This article is an open access publication

\begin{abstract}
The aim of this study was to investigate the influence of specific environmental factors, such as temperature, $\mathrm{pH}$, oxygen concentration, and phosphate, nitrate, chloride, sodium, potassium, sulphate, magnesium and calcium ions concentration, as well as microcystins, on the seasonal variations in the activity of the antioxidant system of the zebra mussel. We examined changes in lipid peroxidation (LPO) levels, glutathione content and the catalase activity of mussels inhabiting the two ecosystems, which differ due to their trophic structure and the presence of toxic cyanobacteria. The results show a relationship between the activity of the antioxidant system of zebra mussels and the seasonal fluctuations of environmental parameters: the symptoms of oxidative stress were generally the highest during spring and the lowest during summer in both
\end{abstract}

Handling Editor: Piet Spaak

Electronic supplementary material The online version of this article (doi:10.1007/s10452-017-9617-4) contains supplementary material, which is available to authorized users.

A. Wojtal-Frankiewicz ( $₫)$ · P. Frankiewicz · T. Jurczak Department of Applied Ecology, Faculty of Biology and Environmental Protection, University of Lodz, Banacha 12/16 Str, 90-237 Lodz, Poland

e-mail: adwoj@biol.uni.lodz.pl

P. Frankiewicz

e-mail: franek@biol.uni.lodz.pl

T. Jurczak

e-mail: tjurczak@biol.uni.lodz.pl ecosystems. Our study also revealed that regardless of the study area the most important factors determining the activity of the antioxidant defences of mussels were the mineral composition (particularly magnesium and calcium ions concentrations) and physical parameters of the water (oxygen concentration and $\mathrm{pH}$ ). However, factors resulting from the trophic status of studied ecosystems, such as limitations in food resources or high concentration of microcystins during cyanobacterial blooms, were periodically responsible for increased level of LPO in the tissues of zebra mussel. These findings may indicate a limited tolerance of the zebra mussel to the local environmental conditions.

Keywords Catalase $\cdot$ Glutathione $\cdot$ Lipid peroxidation $\cdot$ Microcystins $\cdot$ Magnesium $\cdot$ Calcium

\section{Introduction}

Reactive oxygen species (ROS), such as superoxide anions $\left(\mathrm{O}_{2}{ }^{-}\right)$, hydrogen peroxide $\left(\mathrm{H}_{2} \mathrm{O}_{2}\right)$ and hydroxyl

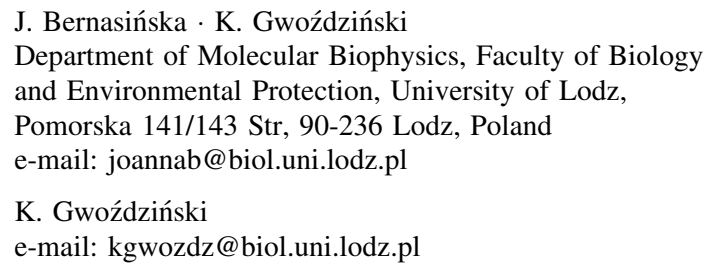


radicals $\left({ }^{\circ} \mathrm{OH}\right)$, are generated endogenously during aerobic respiration in cells, as well as during their interactions with the exogenous xenobiotics (Ray et al. 2012). These pro-oxidative products are highly reactive; at low concentration, ROS regulate several physiological processes, but at higher concentration they may cause damage to cellular components, such as nucleic acids, proteins and lipids (Metcalfe and Alonso-Alvarez 2010). The harmful effects of ROS are limited by the cellular antioxidant system, which generally consists of antioxidant enzymes and molecules without enzymatic activity (Manduzio et al. 2005). However, when the rate of ROS production exceeds the capacity of the antioxidant defence and repair mechanisms, an oxidative stress is generated, which leads to cellular dysfunctions (Costantini 2008). An assessment of the level of oxidative stress is usually achieved by measuring the activity of antioxidant enzymes and the production rates of the nonenzymatic molecules (e.g. glutathione and vitamins) (Manduzio et al. 2005).

One of the most important antioxidant enzymes is catalase (CAT), which is characterized by an early response to contamination (Wenning et al. 1988). This heme-based protein catalyses the conversion of hydrogen peroxide to water and oxygen. The antioxidative effectiveness of catalase varies depending on the species and type of stressor, as well as the exposure time, and it is used as an indicator of oxidative stress (Osman et al. 2007). The next key intracellular antioxidant is glutathione (GSH). This tripeptide has various functions in living organisms. For instance, it is involved in the regulation and maintenance of the cellular redox status and the activity of certain enzymes, and it plays a role in the cellular protection against reactive species and electrophiles (Lushchak 2012). Moreover, GSH acts as a co-enzyme for various reactions and as a co-substrate for significant enzymes (e.g. glutathione peroxidase-GPxs, glutathione reductase-GR). Thus, GSH also indirectly supports the detoxification of radical compounds (Manduzio et al. 2005). A decrease in GSH content is usually related to intensive detoxification or/and with the presence of oxidative stress. Field and experimental research on molluscs has revealed that a decrease in antioxidant enzymes and the glutathione pool results in an increase in lipid peroxidation (LPO) (Doyotte et al. 1997; Cossu et al. 2000). This is due to the destruction of phospholipids in membranes via oxidation, which increase the permeability of the membranes and can lead to the cell's death (Gutteridge and Halliwell 1990).

Different types of pollutants, including heavy metals and xenobiotic and organic compounds, can enhance the formation of ROS in aquatic ecosystems, which intensifies the antioxidant defence and can cause oxidative stress in animals (Valavanidis et al. 2006). However, studies on both marine and freshwater mussels have demonstrated seasonal fluctuations in the activity of the antioxidant system that depend on environmental factors (e.g. temperature, oxygen concentration, salinity, UV radiation, the quantity of food and the availability of nutrients) and the physiological status of the organisms (reproductive status and season-related growth rates) (Viarengo et al. 1991; Bocchetti et al. 2008; Borković-Mitić et al. 2011). Many recent reports have also shown that microcystins (MCs), compounds produced by toxic strains of cyanobacteria, generate oxidative stress in diverse aquatic species (see review of Amado and Monserrat 2010) by inhibiting protein phosphatases 1 and 2A (PP1 and PP2A) and therefore disrupting their balance with protein kinases, as well as leading to the production of ROS (Zegura et al. 2004; Wiegand and Pflugmacher 2005).

A multitude of potential stressors and their often complex relationships complicates assessments seeking to determine which of these factors cause specific responses in an organism. The influence of environmental factors on the seasonal changes in the activity of the antioxidant system may also limit and impede the interpretation of the results concerning the role of pollutants in the generation of oxidative stress. Moreover, the responses of organisms may result from adaptations to a broad range of natural environmental stressors (Lushchak 2011). The species exceptionally tolerant in relation to variable environmental conditions is zebra mussel (Dreissena polymorpha). This is due to the fact that their populations express high genetic diversity and thus have a high potential for genetic adaptation (De Ventura et al. 2016). A broad physiological tolerance of $D$. polymorpha to different habitats causes that this mollusc is one of the most important invaders in fresh waters of Europe and North America (e.g. McMahon 1996; Padilla 2005). Increased resistance of organisms to the various environmental factors as a result of rapid adaptation to local conditions after invasion may be associated with enhanced efficiency of the antioxidant defences. 
However, despite the extensive literature on the biology, ecology and physiology of the zebra mussel, research concerning the impact of environmental factors on the antioxidant system of this species is still rare. Most of the related research, both field and experimental, concerns marine species of molluscsmainly oysters and different species from the Mytilidae family (Manduzio et al. 2005; Chainy et al. 2016). Therefore, the aims of this study were to examine: (1) which of the selected environmental factors (temperature, $\mathrm{pH}$, oxygen concentration, conductivity, or the concentrations of the eight chosen ions and microcystins) induces seasonal variability in the activity of the antioxidant system and oxidative stress in zebra mussels and (2) whether the responses of the antioxidant system depend on the environmental characteristics of ecosystem. Thus, we analysed and compared LPO level, total GSH content and CAT activity in the whole tissue of mussels, which were collected over three years from the two ecosystems differing in depth, trophy, oxygen saturation and water quality. The chosen biomarkers are one of the most acknowledged indicators of oxidative stress, what is justified by results of numerous studies (e.g. Mates 2000; Osman et al. 2007; Niki 2008; Lushchak 2012).

\section{Methods}

\section{Study sites}

Sulejow Reservoir is a 39-year-old, shallow, lowland dam reservoir situated at $138.9 \mathrm{~km}$ of the Pilica River (the Vistula River catchment) in central Poland (Fig. 1). Its characteristics are presented in Online Resource 1. The mean water retention time in the reservoir is 30 days (Wagner et al. 2009). The Sulejow Reservoir is a eutrophic ecosystem with annual cyanobacterial blooms (Tarczyńska et al. 2001; Wagner et al. 2009). The dominant species of bloomforming cyanobacteria is Microcystis aeruginosa, which produces microcystin-LR, YR and RR (Tarczyńska et al. 2001; Jurczak et al. 2005). The genus was determined by verifying the accuracy of the amplification products obtained for the 16S rRNA gene and the mcyA gene, which are specific to the Microcystis genera. In all the analysed samples, we found a strong homology (99-100\%) for M. aeruginosa NIES-843 (Gągała 2013).
Lake Białe is a postglacial ribbon lake situated in the Płock Basin of the Gostynin Lakeland (Fig. 1; characteristics given in Online Resource 1). Lake Białe is characterized by good water quality (mesotrophy) based on data from the National Monitoring Network published by the Provincial Inspectorate for Environmental Protection (PIEP) in Warsaw (Reports of Lake Monitoring; www.wios.warszawa.pl). Microcystins were not detected here.

The sampling dates were established according to the results of long-term monitoring of (1) the Sulejow Reservoir, which has been performed weekly for 25 years from April to October by the Department of Applied Ecology at the University of Lodz (the database from 2010 to 2012 is available in Online Resource 2), and (2) Lake Białe, which has been performed monthly or biweekly for 15 years by PIEP (the database is available at the individual request in the PIEP, www.wios.warszawa.pl). Studies were conducted from spring to autumn in 2010 (three sampling periods: June, August and October-the pilot surveys) and in 2011 and 2012 (four sampling periods: June, July, August and October, in each year). Both in the reservoir and in the lake, the sites of maximum density of mussels were selected. In the Sulejow Reservoir, individual zebra mussels were collected at a site along the shore (maximal depth of $2 \mathrm{~m}$ ) near the dam. In Lake Białe, the site of mussel sampling was located near the shore (maximal depth of $1.5 \mathrm{~m}$ ) at a location halfway along its length (Fig. 1). Collected animals (approximately 30 ind. in each sampling occasion) of similar body length $(1.8 \pm 0.1 \mathrm{~cm})$ were transported to the laboratory in 5-1 glass jars filled with reservoir/lake water (Online Resource 3). During the transport, water was maintained at the same temperature as in the natural environment by placing jars in a Styrofoam box. Distance from both water bodies to laboratory was similar and transportation time was approximately $1 \mathrm{~h}$. In the laboratory, mussels were quickly drained of water, frozen on dry ice and then stored at $-70{ }^{\circ} \mathrm{C}$ before use for the biochemical analyses.

Physical and chemical water analyses

The water temperature $\left({ }^{\circ} \mathrm{C}\right)$, total dissolved oxygen

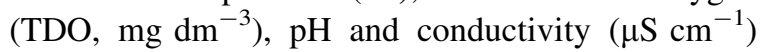
were measured between 10:00 and 11:30 am at both study sites using YSI Professional Plus multisensors. Water for the chemical analyses (1 1 of non-filtered 
Fig. 1 The study areas: Lake Białe and the Sulejow Reservoir and the sites of all parameters sampling

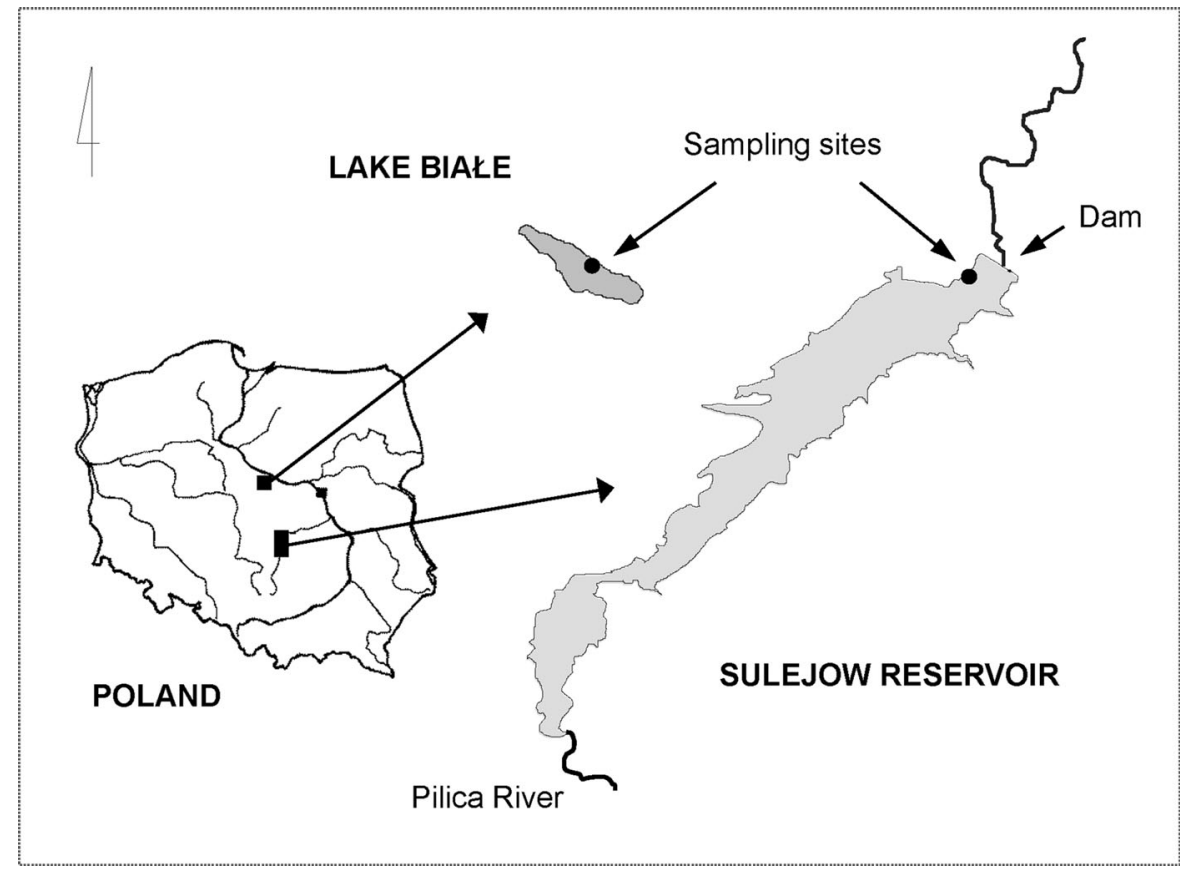

water) was collected at the same time and from the same locations and depths from which the animals were collected in both ecosystems. In the laboratory, the phosphate, nitrate, chloride, sodium, potassium, sulphate, magnesium and calcium ions concentrations were analysed using a Dionex-1000 system, which consists of two ion chromatography ICs that separately analyse anions and cations (ICS-1000; Dionex Corporation, Waltham, MA, USA). The details of this method are described in Wojtal-Frankiewicz et al. (2013).

Estimation of algae and cyanobacteria abundance based chlorophyll a concentration

Water samples were collected from the same sites and at the same time as the animals. The concentration of chlorophyll $a\left(\mu \mathrm{g} \mathrm{dm}^{-3}\right)$ was measured immediately after sampling in a 1-1 water sample using a bbe Algae Online Analyser (AOA, version 1.5 E1, bbe-Moldaenke company Kiel, Germany).

Microcystin concentrations: sample preparation and analyses

Samples of water containing cyanobacteria were stored in dark glass bottles and transported to the laboratory for analyses immediately after sampling. We used 1-1 samples of water from the both ecosystems. The microcystins were analysed as two fractions: the fraction dissolved in water (extracellular) and the cell-bound fraction in the suspended matter (intracellular).

Water samples (1 1) were filtered with Whatman GF/C filter paper to separate cyanobacterial cells from the water. Intracellular microcystins were extracted in a $75 \%$ aqueous methanol solution according to the methods of Meriluoto and Codd (2005). Extracellular microcystins were concentrated in Baker $\mathrm{C}_{18}$ solid-phase extraction (SPE) cartridges (Deventer, Netherlands; sorbent mass: $500 \mathrm{mg}$ ) and eluted using $90 \% \mathrm{MeOH}$ containing $0.1 \%$ trifluoroacetic acid (TFA) according to the methods of Meriluoto and Codd (2005), with some modification. Microcystins were analysed using an HPLC-DAD system as described by Jurczak et al. (2005). Microcystins were identified using the microcystin standards MC-LR, MC-RR and MC-YR based on their characteristic absorption spectra and retention times.

Biochemical analyses

Ten mussels of very similar size were selected from each sample for biochemical analyses. Samples were thawed on ice for approximately 15-20 min when 
valves could be easily opened. After rapid dissection, soft tissue (wet mass $0.89-1.53 \mathrm{~g}$ ) was placed at $10 \%$ $\mathrm{w} / \mathrm{v}$ ratio in $100 \mathrm{mM}$ sodium phosphate buffer, $\mathrm{pH}$ 7.4, with $100 \mathrm{mM} \mathrm{KCl}$ and $1 \mathrm{mM}$ EDTA and maintained on ice until homogenization. In case of determination of glutathione content, soft tissue of $D$. polymorpha was added to a homogenization buffer containing $154 \mathrm{mM} \mathrm{KCl}, 5 \mathrm{mM}$ diethylenetriaminepentaacetic acid (DTPA) and $0.1 \mathrm{M}$ potassium phosphate buffer and $\mathrm{pH} 6.8$ and maintained on ice until homogenization. Homogenization using a CAT X-120 knife homogeniser was performed on ice at $2000 \mathrm{rpm}$ for $2 \mathrm{~min}$, and the homogenates were then centrifuged at $10,000 \times g$ for $10 \min \left(4{ }^{\circ} \mathrm{C}\right)$. An aliquot was removed for protein determination using the Lowry method (Lowry et al. 1951). The supernatants were immediately used for estimations.

For each sampling date, three-six replicates were performed to determine CAT, GSH and LPO values. Exact numbers of replicates are shown in Fig. 2.

\section{Determination of catalase activity}

Determination of catalase activity was performed according to the method of Aebi (1984). The underlying principles of this method are described in our previous work (Wojtal-Frankiewicz et al. 2014). The results are reported in units of CAT activity per milligram of protein ( $\mathrm{U} \mathrm{mg}^{-1}$ protein), where $1 \mathrm{U}$ of CAT is defined as the amount of enzyme needed to decompose $1 \mu \mathrm{mol}$ of $\mathrm{H}_{2} \mathrm{O}_{2}$ per minute.

\section{Determination of glutathione content}

The glutathione (GSH) content was estimated according to the fluorescence assay of Senft et al. (2000) using o-phthalaldehyde (OPA). The underlying principles of this method are described in WojtalFrankiewicz et al. (2014). The glutathione content was calculated using the calibration curve for different concentrations of reduced glutathione as standard and expressed as $\mathrm{nmol} \mathrm{mg}^{-1}$ protein (nanomoles per milligram protein).

Determination of thiobarbituric reactive substances

Lipid peroxidation was measured using a thiobarbituric acid-reactive substances (TBARS) assay (Stocks and Dormandy 1971), with modifications (Rice-Evans et al. 1991). The details of this methodology are described in Wojtal-Frankiewicz et al. (2014). The MDA levels were calculated using the MDA extinction coefficient $\left(156 \mathrm{mmol}^{-1} \mathrm{~cm}^{-1}\right)$ and are expressed as nanomoles per milligram protein (nmol $\mathrm{mg}^{-1}$ protein).

\section{Determination of the protein concentration}

The protein concentration was evaluated using a spectrophotometric method (Lowry et al. 1951) with Folin's reagent. The amount of protein in each sample was estimated using the calibration curve based on different concentrations of bovine albumin, which was used as the standard.

Statistical methods

All statistical analyses were conducted using Statistica 10.0 (StatSoft, Inc). To test for the effects of season and lake on the parameters analysed in 2010-2012, we used a two-way ANOVA with the seasons and lakes as categorical variables and the oxidative stress parameters in $D$. polymorpha tissues as the dependent variables. To test for the effect of year on the ion concentrations in the Sulejow Reservoir and Lake Białe, a one-way ANOVA was used. A principal component analysis (PCA) was used to analyse the relationships between all considered parameters. PCAs were carried out separately for each ecosystem. The ordination diagrams are presented as a projection of the variables (A) and sampling terms (B) on the plane defined by the PCA axes. All statistical analyses were conducted using $\log (x+1)$-transformed data.

\section{Results}

Physical and chemical water analyses

The analyses indicated seasonal and annual variations in the physical parameters, but not any major differences between the two ecosystems. The temperature changed seasonally in both ecosystems, as is typical for the temperate climate zone: the values were low during the spring and autumn and high in summer. The warmest year was 2012 and the coldest was 2010 . Similarly, the highest values for oxygen concentration 

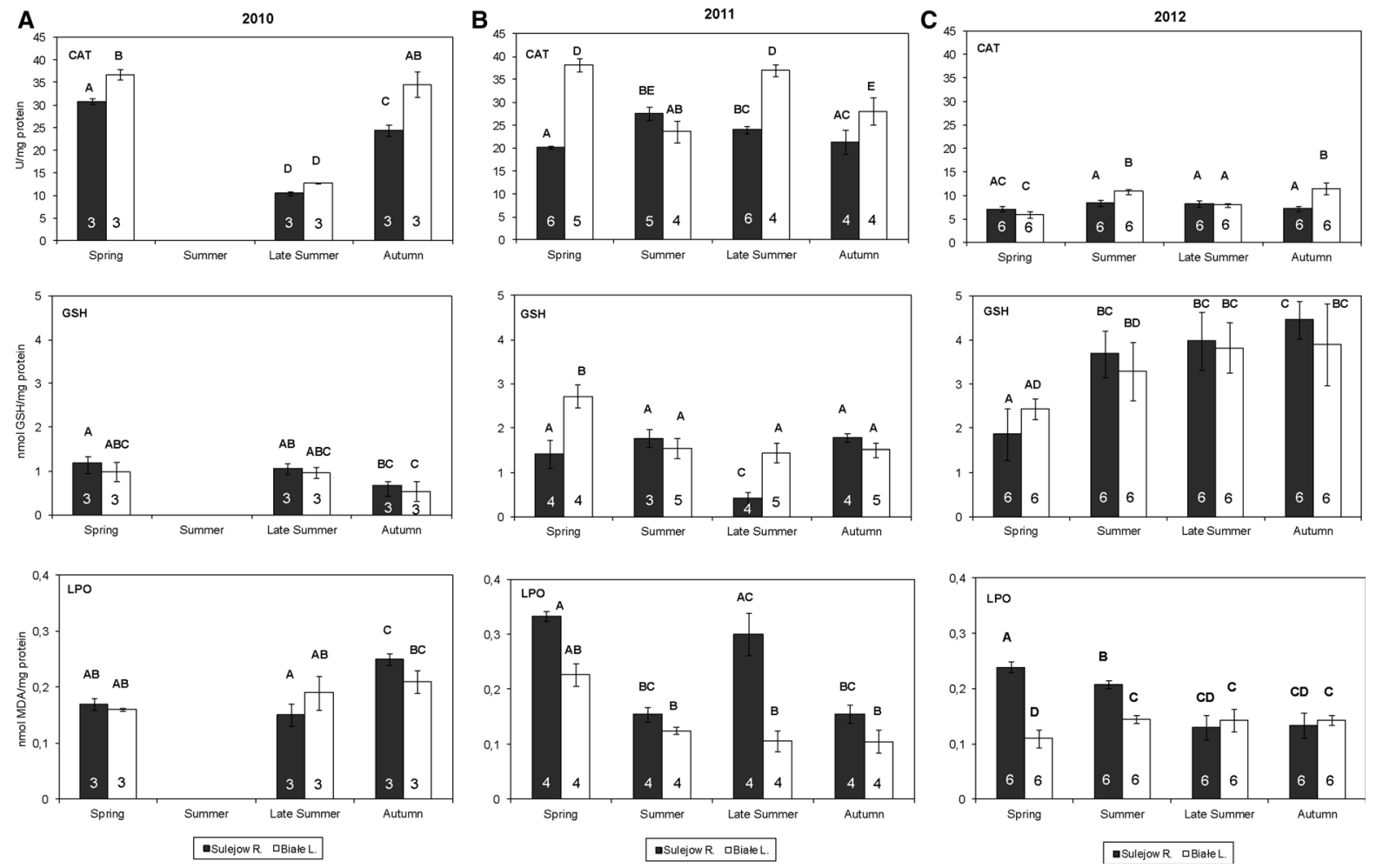

Fig. 2 Comparison of catalase activity $\left(\mathrm{U} \mathrm{mg}^{-1}\right.$ protein), glutathione $(\mathrm{GSH})$ concentrations and lipid peroxidation (LPO) (nmol mg ${ }^{-1}$ protein) in zebra mussel tissues from the Sulejow Reservoir and Lake Białe in 2010 (a), 2011 (b) and

were observed in 2012 and the lowest in 2010. All details are presented in Online Resource 2. The values of the measured chemical parameters changed seasonally and were also different between the ecosystems studied, which reflected the differences in their trophic state. In the Sulejow Reservoir, the concentrations of phosphate ions were usually higher and nitrate ion concentrations were always much higher than in Lake Białe. Calcium ion concentrations were higher in the reservoir than in the lake except in the autumn of 2012. However, the concentrations of chloride, sodium, potassium and sulphate ions were always higher in Lake Białe. Magnesium ion concentrations were only slightly higher in the lake than in the reservoir. All ion concentrations analysed in this study are presented in Online Resource 4.

Results for the effect of year on the ions concentrations (details in Table 1) are summarized as follows:
2012 (c). The bars represent an average value ( \pm SD). Digits inside the bars indicate the number of replicates. The same letters above the bars indicate that the values did not differ significantly
1. In the Sulejow Reservoir, the highest values for sodium, chloride, potassium, sulphate and magnesium ions were observed in 2011, while phosphate and calcium ions were at their highest in 2012. Only nitrate ions reached their highest concentration in 2010.

2. In Lake Białe, the highest concentrations of sodium, chloride and sulphate ions were found in 2011, but the highest values of potassium and magnesium ions appeared in 2010. The highest concentrations of calcium were observed in 2012. The differences between years for nitrate and phosphate ions were not statistically significant.

\section{Chlorophyll a concentration}

The chlorophyll $a$ concentrations were considerably higher in the Sulejow Reservoir than in Lake Białe in all seasons and years studied. In 2010, the total 
Table 1 Results of the one-way ANOVA tests for the effects of year on the ion concentrations in the Sulejow Reservoir and in the Lake Białe
Years with the highest concentration of a given ion are indicated in bold

\begin{tabular}{|c|c|c|c|c|}
\hline Overall effect & $d f$ & $F$ ratio & $P$ value & Tukey's post hoc \\
\hline \multicolumn{5}{|l|}{$\mathrm{NO}_{3}$} \\
\hline Sulejow R. & 2.8 & 134.05 & $<0.001$ & $\mathbf{2 0 1 0}>2011=2012$ \\
\hline Lake Białe & 2.8 & 3.34 & N.S. & \\
\hline \multicolumn{5}{|l|}{$\mathrm{PO}_{4}$} \\
\hline Sulejow R. & 2.8 & 5.84 & $=\mathbf{0 . 0 2 7}$ & $\begin{array}{l}2010=2011 \\
2011=2012\end{array}$ \\
\hline Lake Białe & 2.8 & 3.08 & N.S. & \\
\hline \multicolumn{5}{|l|}{$\mathrm{Cl}$} \\
\hline Sulejow R. & 2.8 & 9.21 & $=0.008$ & $2010<\mathbf{2 0 1 1}>2012$ \\
\hline Lake Białe & 2.8 & 82.40 & $<0.001$ & $2010<\mathbf{2 0 1 1}>2012$ \\
\hline \multicolumn{5}{|l|}{$\mathrm{S}$} \\
\hline Sulejow R. & 2.8 & 47.5 & $<0.001$ & $2011>2010=2012$ \\
\hline Lake Białe & 2.8 & 117.33 & $<0.001$ & $2010=\mathbf{2 0 1 1}>2012$ \\
\hline \multicolumn{5}{|l|}{$\mathrm{Na}$} \\
\hline Sulejow R. & 2.8 & 6.65 & $=\mathbf{0 . 0 2 0}$ & $\mathbf{2 0 1 1}>2010=2012$ \\
\hline Lake Białe & 2.8 & 56.16 & $<0.001$ & $\mathbf{2 0 1 1}>2010>2012$ \\
\hline \multicolumn{5}{|l|}{$\mathrm{K}$} \\
\hline Sulejow R. & 2.8 & 20.72 & $<0.001$ & $\mathbf{2 0 1 1}>2010=2012$ \\
\hline Lake Białe & 2.8 & 3997.00 & $<0.001$ & $\mathbf{2 0 1 0}>2011>2012$ \\
\hline \multicolumn{5}{|l|}{$\mathrm{Mg}$} \\
\hline Sulejow R. & 2.8 & 33.84 & $<0.001$ & $\mathbf{2 0 1 1}>2010=2012$ \\
\hline Lake Białe & 2.8 & 11.79 & $=0.004$ & $\mathbf{2 0 1 0}=2011>2012$ \\
\hline \multicolumn{5}{|l|}{$\mathrm{Ca}$} \\
\hline Sulejow R. & 2.8 & 4.61 & $=0.046$ & $\begin{array}{l}2010=2011 \\
2010=2012\end{array}$ \\
\hline Lake Białe & 2.8 & 6.16 & $=0.024$ & $\begin{array}{l}2010=2011 \\
2010=2012\end{array}$ \\
\hline
\end{tabular}

chlorophyll $a$ concentration in the Sulejow Reservoir reached 17.39 in spring, 30.01 in late summer and $8.07 \mu \mathrm{g} \mathrm{dm}^{-3}$ in autumn, while in Lake Białe, they were, $4.43,6.87$ and $2.93 \mu \mathrm{g} \mathrm{dm}^{-3}$, respectively. In the Sulejow Reservoir, the highest cyanobacteria abundance $\left(24.18 \mu \mathrm{g} \mathrm{dm}^{-3}\right.$ ) was observed during late summer. In 2011, the differences in the concentrations of chlorophyll $a$ were still substantial between ecosystems, especially during summer when the massive cyanobacterial blooms appeared in the Sulejow Reservoir. The chlorophyll $a$ concentration at that time reached $109.21 \mu \mathrm{g} \mathrm{dm}^{-3}$ (the cyanobacterial share was $100 \%$ ), while it was only $5.21 \mu^{2} \mathrm{dm}^{-3}$ in Lake Białe. In the subsequent seasons, cyanobacterial abundance decreased in the reservoir, and the total chlorophyll $a$ concentration was $13.27 \mu \mathrm{g} \mathrm{dm}^{-3}$ in late summer and $26.12 \mu \mathrm{g} \mathrm{dm}^{-3}$ in autumn. During these periods in Lake Białe, the total chlorophyll $a$ concentration reached 6.97 and $5.99 \mu \mathrm{g} \mathrm{dm}^{-3}$, respectively. In 2012, the total chlorophyll $a$ concentration in the Sulejow Reservoir was 8.61 in spring, 21.96 in summer, 10.28 in late summer and $26.66 \mu \mathrm{g} \mathrm{dm}^{-3}$ in autumn. The share of cyanobacteria in the total phytoplankton abundance was relatively low during all seasons. In Lake Białe, the dynamics of the total chlorophyll $a$ concentration were similar to those in 2011 (6.12 in spring, 5.72 in summer, 4.37 in late summer and $5.04 \mu \mathrm{g} \mathrm{dm}^{-3}$ in autumn) (all details in Online Resources 5 and 6).

Microcystin concentrations

HPLC analysis detected the presence of microcystins in the cells but not in the water of the Sulejow 
Reservoir. In the samples, the microcystins LR and RR were identified. MC-RR was the predominant form of the total microcystin content during all years. In 2010, the concentration of MC-RR was 1.62 in spring, 5.54 in late summer and $5.60 \mu \mathrm{g} \mathrm{g}^{-1}$ in autumn, while the concentration of MC-LR was 1.04, 2.56 and $2.63 \mu \mathrm{g} \mathrm{g}^{-1}$, respectively. In 2011 , despite massive algal blooms, the concentration of microcystins in the cells was not excessively high. The concentration of MC-RR was 0.62 in spring, 1.62 in summer, 2.41 in late summer and $2.66 \mu \mathrm{g} \mathrm{g}^{-1}$ in autumn. The concentration of MC-LR was 0.29 in spring, 0.9 in summer, 1.37 in late summer and $0.32 \mu \mathrm{g} \mathrm{g}^{-1}$ in autumn. In 2012, the same general trend of an increase in the concentration of microcystins over time (from spring to autumn) was still observed. However, both cyanobacterial abundance and the concentrations of microcystins in cells were at their lowest in this year. The MC-RR concentration reached 0.35 in spring, 1.06 in summer, 1.67 in late summer and $1.87 \mu \mathrm{g} \mathrm{g}^{-1}$ in autumn, and the MC-LR concentration was only $0.16,0.19,0.21$ and $0.59 \mu \mathrm{g} \mathrm{g}^{-1}$, respectively. The total concentration of microcystins in all seasons and years studied are presented Online Resource 5.

\section{Oxidative stress parameters in zebra mussel tissues}

The results indicate significant seasonal differences in the values of all oxidative stress parameters studied in zebra mussels among the three years (Table 2; Fig. 2).

In 2010 , the catalase activity was the highest in spring (30.79-36.72 $\mathrm{U} \mathrm{mg}^{-1}$ protein) and the lowest in late summer in mussels from both the Sulejow Reservoir and L. Białe. The contents of GSH from mussels from both bodies of water were similar during spring and late summer but were significantly lower in autumn. Lipid peroxidation was the highest in autumn and reached similarly low levels in spring and late summer. In 2010, the between-lake differences were significant only for catalase activity, with higher values observed in mussels from Lake Białe. Significant season $\times$ lake interactions were only observed for CAT and LPO, indicating major intra-seasonal differences between the mussels from each lake in the values of these parameters (Table 2; Fig. 2a).

In 2011, the catalase activity was more stable in mussels from the reservoir (with the highest values reaching $27.59 \mathrm{U} \mathrm{mg}^{-1}$ protein in summer) than in those from the lake. Indeed, the analysis showed significant differences between mussels from each body of water (higher values in mussels from L. Białe) and mussels collected in different seasons, as well as a significant season $\times$ lake interaction. In Lake Białe mussels, a significantly higher CAT activity was observed in spring and late summer than in summer and autumn (Fig. 2b). The contents of GSH were similar during spring, summer and autumn (approximately $1.8 \mathrm{nmol} \mathrm{GSH} / \mathrm{mg}$ protein) but were very low (0.41 nmol GSH/mg protein) during late summer in mussels from the Sulejow Reservoir (Fig. 2b). The GSH level in mussels from Lake Białe was significantly higher in spring (2.72 $\mathrm{nmol} \mathrm{GSH} / \mathrm{mg}$ protein) but did not differ during summer, late summer and autumn. Similar to the results for CAT activity, a twoway ANOVA indicated significant differences in GSH contents between the mussels from each body of water and mussels collected in different seasons, as well as a significant season $\times$ lake interaction (Table 2). For the LPO results, the ANOVA indicated significant differences between mussels from each body of water and those collected in different seasons, but the season $\times$ lake interaction was not significant (Table 2). The LPO levels in mussels from the Sulejow Reservoir were significantly higher in spring and late summer (approximately $0.33 \mathrm{nmol} \mathrm{MDA} / \mathrm{mg}$ protein) than in summer and autumn $(0.15 \mathrm{nmol}$ $\mathrm{MDA} / \mathrm{mg}$ protein). In Lake Białe mussels, the LPO levels were relatively low in summer, late summer and autumn (0.106-0.125 nmol MDA/mg protein) compared with levels in the spring $(0.227 \mathrm{nmol} \mathrm{MDA} / \mathrm{mg}$ protein); however, these differences were not significant (Fig. 2b).

In 2012, the CAT activity was the lowest of all the years (it did not exceed $12 \mathrm{U} \mathrm{mg}^{-1}$ protein). In the mussels from the reservoir, there were no significant differences between the seasons in CAT activity, while in those from the lake, CAT activity was similar in spring and late summer and significantly higher in summer and autumn. Thus, the analysis showed significant differences between the mussels from the two bodies of water (higher values in L. Białe mussels) and significant season $\times$ lake interactions in CAT activity. In contrast, the GSH contents were highest in 2012. They did not differ between ecosystems, but varied significantly among the studied seasons: GSH levels were lower in spring than in summer, late summer and autumn. Seasonal changes were also observed in lipid peroxidation in mussels from both 
Table 2 Results of the two-way ANOVA tests for the effects of season and ecosystem type on the oxidative stress parameters measured in D. polymorpha tissues
$L P O$ lipid peroxidation, $G S H$ glutathione, $C A T$ catalase

\begin{tabular}{|c|c|c|c|c|}
\hline Overall effect & $d f$ & $F$ ratio & $P$ value & Tukey's post hoc \\
\hline \multicolumn{5}{|l|}{2010} \\
\hline \multicolumn{5}{|l|}{ LPO } \\
\hline Seasons & 2.12 & 23.74 & $<0.001$ & \multirow[t]{3}{*}{ Spr $=$ Sum $<$ Aut } \\
\hline Lakes & 1.12 & 0.015 & N.S. & \\
\hline Seasons $\times$ lakes & 1.12 & 7.74 & $<0.01$ & \\
\hline \multicolumn{5}{|l|}{ GSH } \\
\hline Seasons & 2.12 & 14.75 & $<0.001$ & \multirow[t]{3}{*}{$\mathrm{Spr}=\mathrm{Sum}>$ Aut } \\
\hline Lakes & 1.12 & 3.35 & N.S. & \\
\hline Seasons $\times$ lakes & 1.12 & 0.19 & N.S. & \\
\hline \multicolumn{5}{|l|}{ CAT } \\
\hline Seasons & 2.12 & 434.95 & $<0.001$ & \multirow{3}{*}{$\begin{array}{l}\text { Spr }>\text { Aut }>\text { Sum } \\
\text { Sulejow R. }<\text { Lake Białe }\end{array}$} \\
\hline Lakes & 1.12 & 88.00 & $<0.001$ & \\
\hline Seasons $\times$ lakes & 1.12 & 12.05 & $<0.01$ & \\
\hline \multicolumn{5}{|l|}{2011} \\
\hline \multicolumn{5}{|l|}{ LPO } \\
\hline Seasons & 3.24 & 8.72 & $<0.001$ & $\begin{array}{l}\text { Sum }=\text { L.Sum }=\text { Aut } \\
\text { Spr }=\text { L.Sum }\end{array}$ \\
\hline Lakes & 1.24 & 16.36 & $<0.001$ & Sulejow R. $>$ Lake Białe \\
\hline Seasons $\times$ lakes & 3.24 & 2.47 & N.S. & \\
\hline \multicolumn{5}{|l|}{ GSH } \\
\hline Seasons & 3.26 & 42.12 & $<0.001$ & \multirow{3}{*}{$\begin{array}{l}\text { Spr }>\text { Sum }=\text { Aut }>\text { L.Sum } \\
\text { Sulejow R. }<\text { Lake Białe }\end{array}$} \\
\hline Lakes & 1.26 & 38.42 & $<0.001$ & \\
\hline Seasons $\times$ lakes & 3.26 & 30.65 & $<0.001$ & \\
\hline \multicolumn{5}{|l|}{ CAT } \\
\hline Seasons & 3.30 & 22.89 & $<0.001$ & \multirow{3}{*}{$\begin{array}{l}\text { Spr }=\text { L.Sum }>\text { Sum }=\text { Aut } \\
\text { Sulejow R. }<\text { Lake Białe }\end{array}$} \\
\hline Lakes & 1.30 & 217.34 & $<0.001$ & \\
\hline Seasons $\times$ lakes & 3.30 & 70.98 & $<0.001$ & \\
\hline \multicolumn{5}{|l|}{2012} \\
\hline \multicolumn{5}{|l|}{ LPO } \\
\hline Seasons & 3.40 & 23.45 & $<0.001$ & \multirow{3}{*}{$\begin{array}{l}\text { Spr }=\text { Sum }>\text { L.Sum }=\text { Aut } \\
\text { Sulejow R. }>\text { Lake Białe }\end{array}$} \\
\hline Lakes & 1.40 & 89.33 & $<0.001$ & \\
\hline Seasons $\times$ lakes & 3.40 & 55.48 & $<0.001$ & \\
\hline \multicolumn{5}{|l|}{ GSH } \\
\hline Seasons & 3.40 & 26.71 & $<0.001$ & \multirow[t]{3}{*}{$\begin{array}{l}\text { Sum }=\text { L.Sum } \\
\text { L.Sum }=\text { Aut }\end{array}$} \\
\hline Lakes & 1.40 & 0.62 & N.S. & \\
\hline Seasons $\times$ lakes & 3.40 & 2.04 & N.S. & \\
\hline \multicolumn{5}{|l|}{ CAT } \\
\hline Seasons & 3.40 & 47.63 & $<0.001$ & \multirow{3}{*}{$\begin{array}{l}\text { Spr }<\text { L.Sum }<\text { Sum }=\text { Aut } \\
\text { Sulejow R. }<\text { Lake Białe }\end{array}$} \\
\hline Lakes & 1.40 & 38.82 & $<0.001$ & \\
\hline Seasons $\times$ lakes & 3.40 & 37.27 & $<0.001$ & \\
\hline
\end{tabular}

bodies of water. In the mussels from Sulejow Reservoir, the LPO level was significantly higher than in those from Lake Białe (Table 2; Fig. 2c): it reached
0.24 and $0.21 \mathrm{nmol} \mathrm{MDA} / \mathrm{mg}$ protein in spring and summer, respectively, but did not exceed $0.14 \mathrm{nmol}$ $\mathrm{MDA} / \mathrm{mg}$ protein during late summer and autumn. In 
mussels from Lake Białe, the LPO level was the lowest $(0.11 \mathrm{nmol} \mathrm{MDA} / \mathrm{mg}$ protein) in spring, but was similarly higher in other seasons. The results also show significant season $\times$ lake interactions for LPO levels.

\section{Results of the PCA analysis}

The results of the principal component analysis show that all ions determining salinity (sodium, chloride, potassium) were positively correlated in both the Sulejow Reservoir and Lake Białe (Figs. 3, 4; Table 3). This "salinity complex" was always positively correlated with sulphate and magnesium ions. These parameters were related to the $\mathrm{PC} 1$ axis in the analyses for both ecosystems. The results of the PCA also indicate a clear separation of the studied years. Only the two first components with the highest eigenvalues were plotted for analysing the relationships between variables in both ecosystems as including other factors did not provide any additional significant information for interpreting the ecological relevance of the data.

In the Sulejow Reservoir, the first axis (PC1) showed the "salinity complex", sulphate ions, magnesium ions, conductivity and CAT as the main positive contributors and calcium ions as the main negative contributor (Fig. 3a) (only parameters having a correlation with the PC axis higher than 0.5 or lower than -0.5 were indicated here and elsewhere). High concentrations of sodium, chloride, potassium, sulphate and magnesium ions were observed in the seasons of 2011 in the reservoir (Fig. 3b; Table 1). The second axis (PC2) was positively linked with oxygen concentration, $\mathrm{pH}, \mathrm{GSH}$ and phosphates and negatively linked with nitrites, microcystins and CAT activity (Fig. 3a). High values for $\mathrm{pH}$ and oxygen, GSH and phosphate contents were observed in 2012, while high CAT activity and nitrate and microcystin concentrations were observed in 2010 (Figs. 2, 3b; Table 1).

In Lake Białe, the "salinity complex", sulphates ions, magnesium ions and CAT activity were distinguished as the main, but this time negative, contributors to the PC1 axis, and calcium, nitrates, GSH, pH and oxygen concentration were the main positive contributors (Fig. 4a). Potassium and magnesium ions had the highest concentrations in 2010, while sodium, chloride and sulphate ions reached their highest values in 2011 (Fig. 4b; Table 1). CAT activity was high in both 2010 and 2011. In turn, 2012 was characterized by the highest values for GSH content and calcium concentration (Fig. 2). The main positive contributor to the PC2 axis was LPO, and the main negative contributors were phosphates and chloride concentrations, algae content, temperature and $\mathrm{pH}$ (Fig. 4a). The highest lipid peroxidation level was observed in 2010 (Fig. 2), but most of the negative contributors were not specific to a particular year.

\section{Discussion}

Both in Lake Białe and in the Sulejow Reservoir, oxygen concentration was positively correlated with GSH content and negatively correlated with catalase activity (Figs. 3, 4; Table 3), indicating that zebra mussels prefer sufficiently high concentrations of oxygen in the water. Cohen (2009) reported that zebra mussels are usually found where dissolved oxygen is in the range of $4-10.2 \mathrm{mg} \mathrm{dm}^{-3}$ at $10-25^{\circ} \mathrm{C}$ in surface waters. In our study, the concentration of oxygen varied from 5.67 to 11.56 in 2010-2011, while in 2012, it was generally higher (Online Resource 4), and this year showed the largest effect on the results of the PCA.

Temperature was strongly, negatively correlated with LPO in L. Białe, which means that high levels of oxidative stress were generated at lower temperature (Fig. 4; Table 3). The lower temperature limit for the growth of adult zebra mussel in European lakes ranged from 11 to $12{ }^{\circ} \mathrm{C}$ (Stańczykowska 1977), and these values were observed in both studied ecosystems during the autumn of $2010\left(11.5^{\circ} \mathrm{C}\right)$. Nevertheless, an analogous correlation between temperature and LPO level in the Sulejow Reservoir was negligible, and furthermore, correlations between temperature and GSH content (positive) and CAT activity (negative) were weak (Fig. 3; Table 3). Cold stress, which is associated with an increase in intracellular oxidative stress and with the activity of antioxidants, has mainly been examined in plants and bacteria (Chattopadhyay 2002). Some of these studies have indicated that during the exposure of plant cells to low temperatures, the rate of enzymatic reactions is reduced, leading to a decrease in the demand for ATP and an accumulation of electrons at certain points of the respiratory chain and, hence, an increase in the production of ROS 
Fig. 3 Results of the principal component analysis (PCA) conducted on data collected on the Sulejow Reservoir:

a Projection of variables on the plane defined by the first two PCA factors.

b Projection of the sampling terms on the plane defined by the first two PCA factors

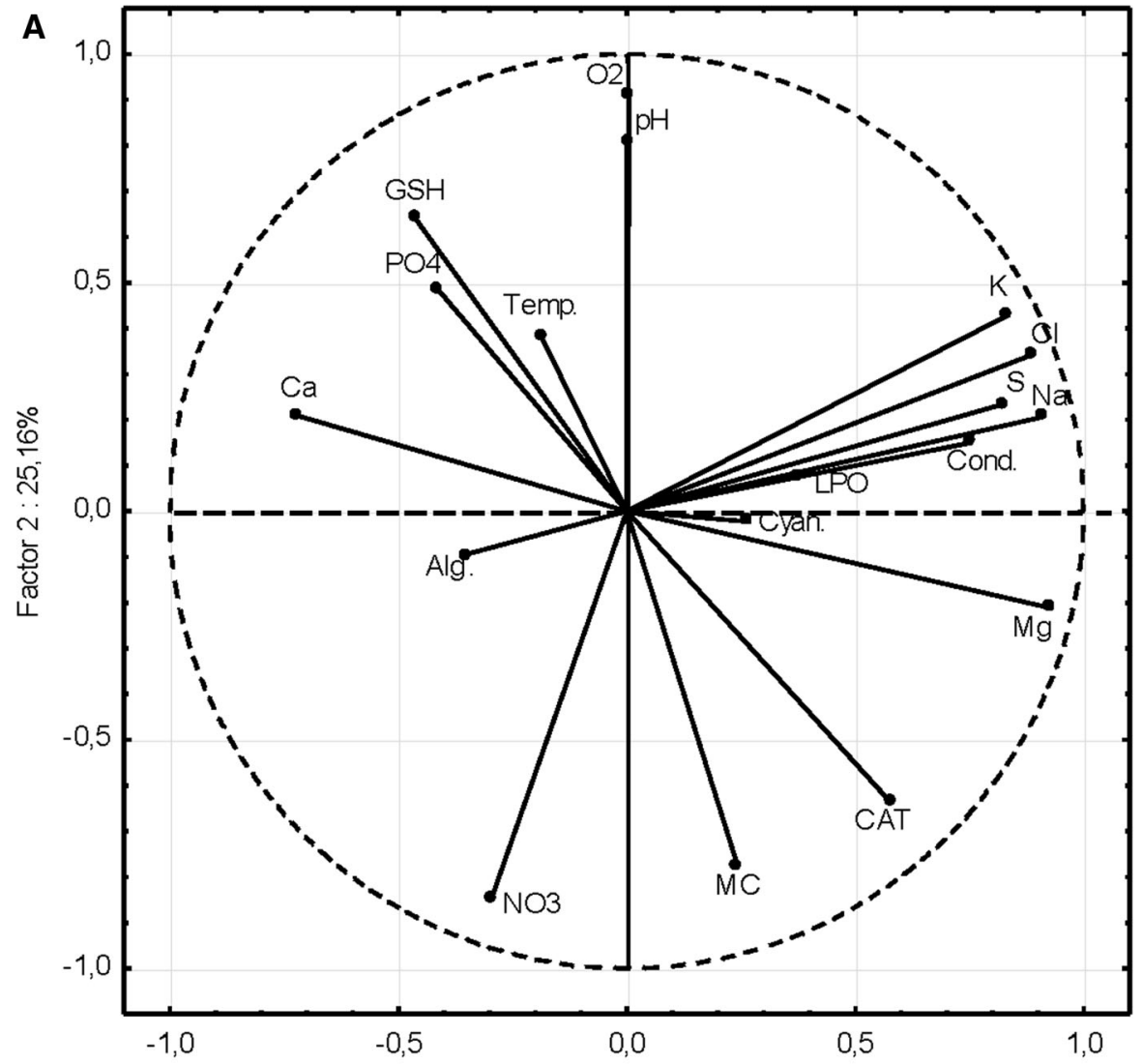

Factor $1: 34,32 \%$

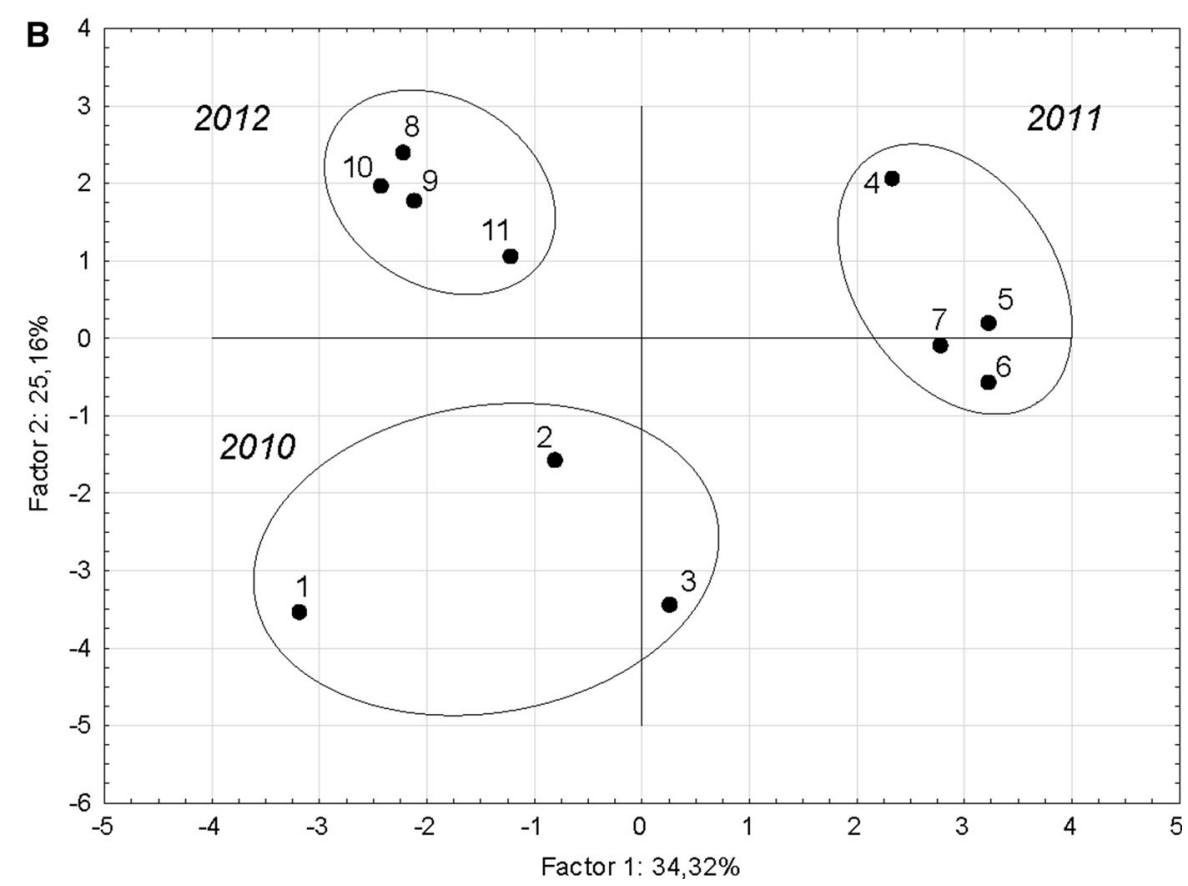


Fig. 4 Results of the principal component analysis (PCA) conducted on data collected on Lake Białe: a Projection of variables on the plane defined by the first two PCA factors. b Projection of the sampling terms on the plane defined by the first two PCA factors. The numbers indicate the consecutive terms of sampling from spring 2010 (1) to autumn 2012 (11)
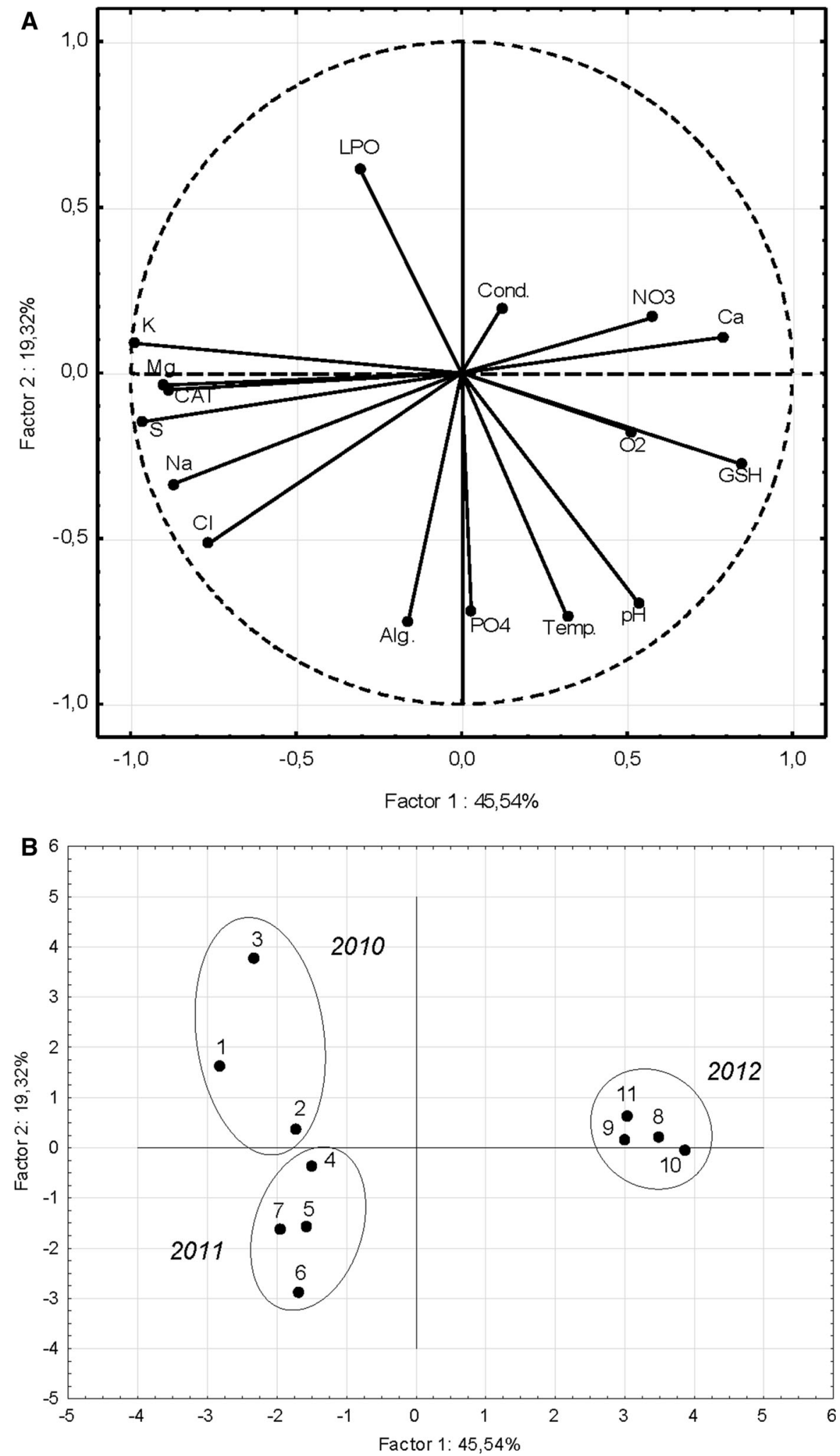


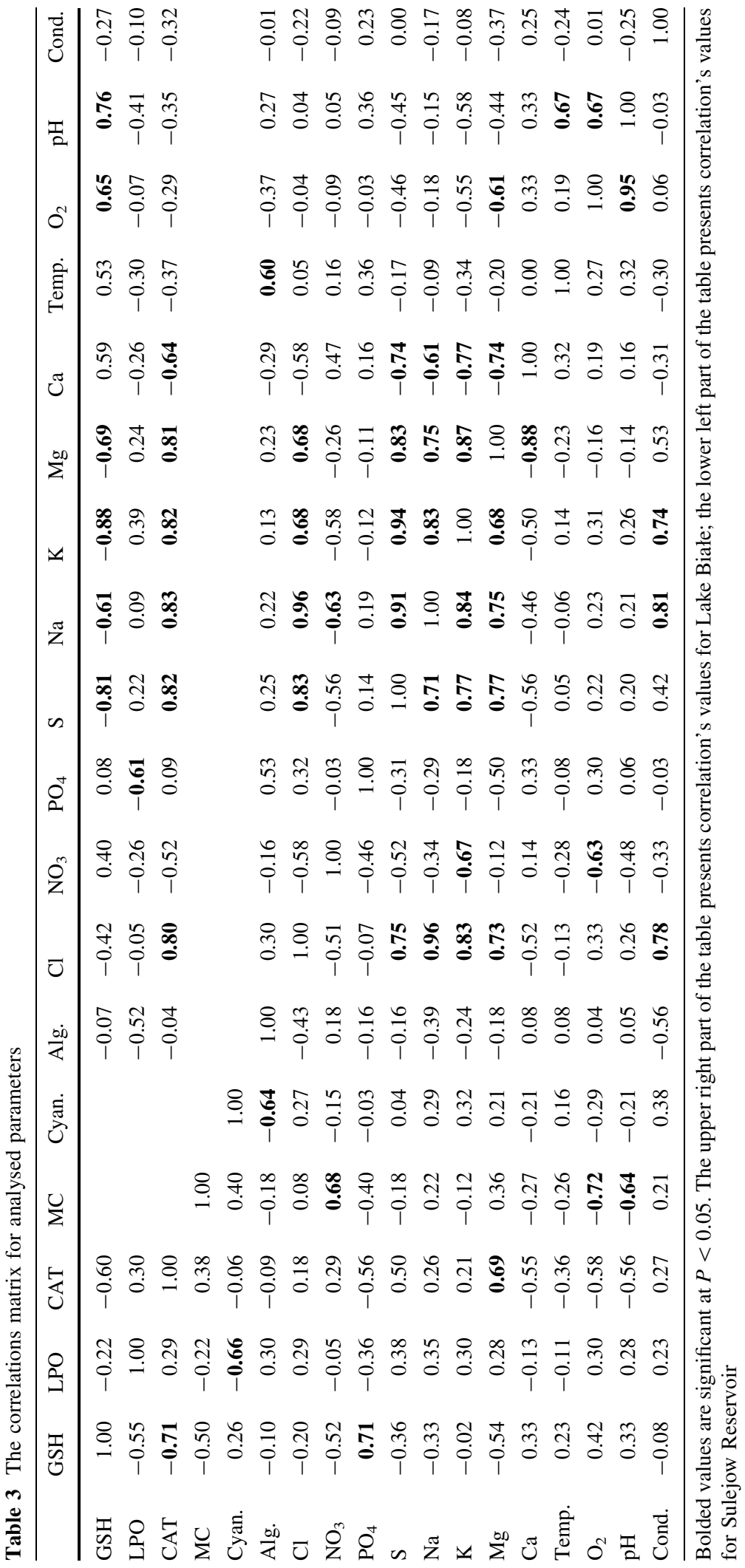


followed by the activation of antioxidant system (Kaye and Guy 1995). Recent experimental research on zebra mussels held at $10{ }^{\circ} \mathrm{C}$ for four weeks showed an elevated AMP-activated protein kinase (AMPK) activity, which serves as a cellular indicator of temperature stress (Jost et al. 2015). The function of AMPK is to monitor the AMP/ATP ratio, and once activated, it regulates metabolic processes to maintain a constant supply of ATP (Hardie and Sakamoto 2006). The results of a study by Jost et al. (2015) suggest that the cellular energy requirement and intensification of AMPK activity are associated with cold acclimation. Thus, the cold-stress mechanism in zebra mussel may be similar to that in plants. In that case, an increase in lipid peroxidation at low temperatures can be considered a symptom of cold stress in zebra mussels.

Analogous to the results for temperature, $\mathrm{pH}$ was also negatively correlated with LPO in Lake Białe (Table 3), indicating that low $\mathrm{pH}$ causes oxidative stress. Field studies by Ramcharan et al. (1992) in 76 European lakes showed that zebra mussels were absent in those with a pH below 7.3. Only slightly higher $\mathrm{pH}$ values (7.4) were found in the spring and autumn of 2010 in Lake Białe. A low pH leads to the disruption of the zebra mussel's ion metabolism. Vinogradov et al. (1993) demonstrated in laboratory experiments that zebra mussels suffer a net loss of sodium and calcium concentrations at $\mathrm{pH}$ below 7. Other research confirms that zebra mussels are less tolerant of low $\mathrm{pH}$ and a low calcium concentration than other freshwater bivalves (McMahon 1991). Our study indicates a weak positive correlation between $\mathrm{pH}$ and calcium concentrations in both bodies of water, but calcium was not significantly correlated with LPO in either ecosystem (Figs. 3, 4; Table 3). This probably resulted from the fact that the calcium concentrations observed in Lake Białe and in the Sulejow Reservoir were well above the lower limit of tolerance for the zebra mussel, which is $28 \mathrm{mg} \mathrm{dm}^{-3}$ (Ramcharan et al. 1992; Karatayev et al. 2007). However, in both ecosystems calcium ions were strongly and positively correlated with GSH content and negatively correlated with CAT activity (Figs. 3, 4; Table 3). Calcium is essential for shell growth, sperm motility, tissue ion balance, larval survival and juvenile growth, and Dreissena appear to have higher calcium requirements than do many other freshwater mussels (Whittier et al. 2008). The upper calcium limit is not known for certain, and according to our results, high levels of calcium ions are related to the stability of the zebra mussel antioxidant system. However, although zebra mussels prefer high concentrations of calcium ions, they can survive in calciumpoor environments provided that the water contains magnesium in minimal amounts (Dietz et al. 1994). Magnesium is one of the most important ions for zebra mussel osmoregulation. Furthermore, high $\mathrm{Mg} / \mathrm{Ca}$ molar ratios in the surrounding water favour the precipitation of aragonite deposits of $\mathrm{CaCO}_{3}$ over calcite, which indicates the crucial regulatory role of magnesium in zebra mussel shell production (Checa et al. 2007). Magnesium is therefore considered to be the limiting factor in the physiology and shell production of zebra mussels (Hallstan et al. 2010). Nonetheless, our research showed that high levels of magnesium ions may stimulate the activity of the zebra mussel antioxidant system. The PCA results indicate a significant, positive correlation between the activity of CAT and magnesium ion concentrations. This relationship was particularly evident in 2011, both in Lake Białe and in the Sulejow Reservoir (Figs. 3, 4; Table 3). Data from previous studies confirm that a magnesium deficiency contributes to lipid peroxidation and oxidative stress; however, these results refer mainly to vertebrates (e.g. Blache et al. 2006; Mazur et al. 2007). Yang et al. (2006) observed a doubling in the amount of hydrogen peroxide produced in cells from chick embryos incubated in a magnesium-deficient medium because the magnesium deficiency reduced the activity of catalase. Our results for zebra mussels agree with those findings.

In both ecosystems, the concentrations of magnesium, chloride, sodium, potassium and sulphate ions were highly correlated with each other (Figs. 3, 4; Table 3), which is not surprising as they are generally interdependent in metabolism processes. Dietz et al. (1994) reported that magnesium, sodium, chloride and potassium are essential for zebra mussel survival and that they need to be in reasonable balance. Particularly important is the presence of potassium because the loss of potassium from cells probably disrupts the electrochemical gradient needed for sodium and chloride ions transport, and thus, even low concentrations of potassium are required for zebra mussels to maintain a sodium and chloride balance (Dietz et al. 1994). However, Lake Białe was characterized by exceptionally high concentrations of potassium; in 2010, the concentration of potassium was close to 
$39 \mathrm{mg} \mathrm{dm}^{-3}$, and populations of zebra mussel are generally not found in waters with levels higher than this (Cohen 2005). The concentrations of chloride, sodium, and sulphate ions were also higher in Lake Białe than in the Sulejow Reservoir during the three years of this study. Furthermore, in Lake Białe, all of the mentioned ions were significantly, positively correlated with CAT activity and significantly, negatively correlated with GSH content (Fig. 4; Table 3). Consequently, high concentrations of ions stimulated catalase activity but did not generate oxidative stress. This could be related to the fact that zebra mussels tend to have lower blood solute concentrations despite their high rates of ion transport. Maintaining these low concentrations of solutes in their blood is possible because zebra mussels have an unusually "leaky" epithelium with a high paracellular permeability to solutes and, thus, an extensive passive loss of ions (Dietz et al. 1996).

Zebra mussels occur in a wide range of trophic conditions in lake; however, their density is variable both in lakes different trophic conditions and in lakes with the same conditions (Lewandowski 2001). In general, zebra mussels prefer waters with moderate levels of nutrients (Cohen 2005). Our research, conducted in a mesotrophic lake and a eutrophic dam reservoir, shows differences in the impact of nutrient levels on the activity of the antioxidant system of zebra mussels. In the Sulejow Reservoir, a significant, positive correlation of phosphates concentrations with GSH content and a negative correlation with CAT activity (Fig. 3; Table 3) indicate that zebra mussels are adapted to a phosphorus-rich environment. This finding is in agreement with long-term field research, which shows that zebra mussels increase the amount of phosphorus in a lake through the excretion of more phosphorus than is filtered (e.g. Zhang et al. 2011; Nalepa and Schloesser 2014), as well as with experiments demonstrating that zebra mussels reduce the nitrogen/phosphorus ratio of water (e.g. Bykova et al. 2006; Wojtal-Frankiewicz and Frankiewicz 2011). Our results also show that low concentrations of phosphates might cause oxidative stress in zebra mussel (significant, negative correlation between phosphates and LPO; Fig. 4; Table 3) in Lake Białe. However, we think that this effect is related to the amount of food available because phosphates were clearly positively correlated with algae abundance. Such a relationship confirms the growth-limiting role of phosphorus for algae production in Lake Białe. The quantity and quality of food can affect the structure of cell membranes and the production of ROS and can contribute to the level of lipid peroxidation (German 1999; Metcalfe and Alonso-Alvarez 2010). Thus, generally low amounts of food of good quality in a lake could generate oxidative stress in zebra mussels.

One of the most important factors that affected the activity of the antioxidant system of zebra mussels in the Sulejow Reservoir was the microcystin concentration. These cyclic heptapeptides induce both acute and chronic toxic effects, as well as behavioural alterations in aquatic organisms (Amado and Monserrat 2010; Ferrão-Filho and Kozlowsky-Suzuki 2011). Microcystins generally remain inside healthy cells; hence, they can be dangerous for filter feeders who absorb toxic cells. Admittedly, zebra mussels can reduce their food ingestion and absorption rate during exposure to the toxic strains of cyanobacteria (Juhel et al. 2006) and can eject toxic cells through their pedal gape during pseudofaeces production (Vanderploeg et al. 2001) and thus reduce the toxic effect of MCs. Consumed cyanotoxins can be accumulated in the tissues of mussels (Pires et al. 2004), and the distribution of toxins in different organs varies, with the highest concentration usually being in the hepatopancreas (Ferrão-Filho and Kozlowsky-Suzuki 2011). However, organisms living in bodies of water with annual toxic cyanobacterial blooms usually develop physiological adaptations to enable the efficient detoxification of microcystins. In the process of MC biodegradation, GSH plays a particularly important role because the chemical conjugation of MCs with GSH reduces the toxicity and facilitates the excretion of cyanotoxins (Pflugmacher et al. 1998). In a laboratory experiment, Peuthert and Wiegand (2004) found that an increase in the activity of antioxidant enzymes was accompanied by a short-term depletion and oxidation of the glutathione pool in zebra mussels exposed on toxic cyanobacterial extracts. Similar results were observed in our field studies. The PCA analysis shows a clear relationship between the concentration of microcystins and the activity of the antioxidant system of the zebra mussels in the Sulejow Reservoir: a positive correlation of MCs with CAT and a negative correlation with GSH content (Fig. 3; Table 3). This was particularly evident in the autumn of 2010 and in the late summer of 2011, when high CAT activity and a strong reduction in the rate of GSH 
production occurred at the same time as the maximal detected values of microcystins for each year were observed. Moreover, high levels of LPO observed on those dates indicate the generation of oxidative stress. In 2012, a parallel relationship was not found, presumably due to much lower concentrations of MCs than in the previous years (Online Resource 5).

\section{Conclusions and perspectives}

The presented results showed that in both ecosystems, seasonal fluctuations of environmental factors determined the activity of the antioxidant system of zebra mussels. The symptoms of oxidative stress in mussels were generally the highest in spring and the lowest in summer in the studied bodies of water. Regardless of the study area, the most important factors affecting the activity of the antioxidant defences of animals were: oxygen concentration, $\mathrm{pH}$ and the concentrations of the analysed ions-particularly calcium and magnesium. However, the oxidative stress could be also generated by the factors, which were specific to the ecosystem, for example the presence of cyanobacterial toxins and limitation of food resources resulting from the trophic status of the ecosystems. These findings should be taken into account in the selection of parameters used in biomonitoring research and in the interpretation of their results. This could be particularly important for criteria used in studies of the invasive potential and distribution of zebra mussels.

Considering the future research, we must also recognize that seasonal changes in the values of oxidative stress parameters result not only from the combination of natural stressors and anthropogenic pollutants but also from the age and phase of the life cycle of the organism. Different lipid levels in tissues of mussels during reproductive and postreproductive period (high vs. low, respectively) may influence the content of hydrophobic contaminants in the body affecting the activity of their antioxidant system (Bruner et al. 1994). To account for such variability, more specifically focusing field research is required.

Acknowledgements This study was supported by the Polish Ministry of Science and Higher Education (Grant No. 3988/B/ P01/2010/39).

Open Access This article is distributed under the terms of the Creative Commons Attribution 4.0 International License (http:// creativecommons.org/licenses/by/4.0/), which permits unrestricted use, distribution, and reproduction in any medium, provided you give appropriate credit to the original author(s) and the source, provide a link to the Creative Commons license, and indicate if changes were made.

Author contributions AWF, JB, PF and KG conceived, designed and performed the experiments.. AWF, JB, PF, KG and TJ analysed the data. AWF, JB, PF, KG and TJ contributed reagents/materials/analysis tools. AWF and PF wrote and edited the manuscript. All authors have approved the final version.

\section{References}

Aebi H (1984) Catalase in vitro. Methods Enzymol 105:121-126

Amado LL, Monserrat JM (2010) Oxidative stress generation by microcystins in aquatic animals: why and how. Environ Int 36:226-235

Blache D, Devaux S, Joubert O, Loreau N, Schneider M, Durand P, Prost M, Gaume V, Adrian M, Laurant P, Berthelot A (2006) Long-term moderate magnesium-deficient diet shows relationships between blood pressure, inflammation and oxidant stress defense in aging rats. Free Radic Biol Med 41:277-284

Bocchetti R, Virno Lamberti C, Pisanelli B, Razzetti EM, Maggi C, Catalano B, Sesta G, Martuccio G, Gabellini M, Regoli F (2008) Seasonal variations of exposure biomarkers, oxidative stress responses and cell damage in the clams, Tapes philippinarum, and mussels, Mytilus galloprovincialis, from Adriatic Sea. Mar Environ Res 66:24-26

Borković-Mitić SS, Kovačević TB, Perendija BR, Despotović SG, Gavrić JP, Pavlović SZ, Saičić ZS (2011) Superoxide dismutase and catalase activities in the digestive gland and gills of the freshwater bivalve Unio pictorum from the Sava River. Arch Biol Sci 63:185-192

Bruner KA, Fisher SW, Landrum PF (1994) The role of the zebra mussel, Dreissena polymorpha, in contaminant cycling: I. The effect of body size and lipid content on the bioconcentration of PCBs and PAHs. J Great Lakes Res 20:725-734

Bykova O, Laursen A, Bostan V, Bautista J, McCarthy L (2006) Do zebra mussels (Dreissena polymorpha) alter lake water chemistry in a way that favours Microcystis growth? Sci Total Environ 371:362-372

Chainy GBN, Paital B, Dandapat J (2016) An overview of seasonal changes in oxidative stress and antioxidant defence parameters in some invertebrate and vertebrate species. Scientifica. doi:10.1155/2016/6126570

Chattopadhyay MK (2002) Low temperature and oxidative stress. Curr Sci (India) 83:109

Checa AG, Jimenez-Lopez C, Rodriguez-Navarro A, Machado JP (2007) Precipitation of aragonite by calcitic bivalves in Mg-enriched marine waters. Mar Biol (Berl) 150:819-827

Cohen AN (2005) A review of zebra mussels' environmental requirements. A report for the California Department of Water Resources. San Francisco Estuary Institute, Oakland 
Cohen AN (2009) Managing the Exotic Mussels Dreissena polymorpha, Dreissena bugensis, Limnoperna fortunei and Mytilopsis leucophaeata in SFPUC's Reservoirs. A Report for the San Francisco Public Utilities Commission. Center for Research on Aquatic Bioinvasions, Richmond, California and San Francisco Estuary Institute Oakland, California

Cossu C, Doyotte A, Babut M, Exinger A, Vasseur P (2000) Antioxidant biomarkers in freshwater bivalves, Unio tumidus, in response to different contamination profiles of aquatic sediments. Ecotoxicol Environ Saf 45:106-121

Costantini D (2008) Oxidative stress in ecology and evolution: lessons from avian studies. Ecol Lett 11:1238-1251

De Ventura L, Sarpe D, Kopp K, Jokela J (2016) Variability in phenotypic tolerance to low oxygen in invasive populations of quagga and zebra mussels. Aquat Invasions 11:267-276

Dietz TH, Lessard D, Silverman H, Lynn JW (1994) Osmoregulation in Dreissena polymorpha: the importance of $\mathrm{Na}, \mathrm{Cl}, \mathrm{K}$ and particularly $\mathrm{Mg}$. Biol Bull 187:76-83

Dietz TH, Wilcox SJ, Byrne RA, Lynn JW, Silverman H (1996) Osmotic and ionic regulation of North American zebra mussels (Dreissena polymorpha). Am Zool 36:364-372

Doyotte A, Cossu C, Jacquin M-C, Babut M, Vasseur P (1997) Antioxidant enzymes, glutathione and lipid peroxidation as relevant biomarkers of experimental or field exposure in the gills and the digestive gland of the freshwater bivalve Unio tumidus. Aquat Toxicol 39:93-110

Ferrão-Filho AS, Kozlowsky-Suzuki B (2011) Cyanotoxins: bioaccumulation and effects on aquatic animals. Mar Drugs 9:2729-2772

Gągała I (2013) Impact of the environmental factors with particular emphasis on the role of bacteria in dynamics of occurrence and toxicity of freshwater cyanobacteria. $\mathrm{PhD}$ Dissertation, University of Lodz, Poland

German JB (1999) Food processing and lipid oxidation. In: Jackson LS, Knize MG, Morgan JN (eds) Impact of processing on food safety, vol 459., Advances in Experimental Medicine and BiologySpringer, New York, pp 23-50

Gutteridge JMC, Halliwell B (1990) The measurement and mechanism of lipid peroxidation in biological systems. Trends Biol Sci 15:129-135

Hallstan S, Grandin U, Goedkoop W (2010) Current and modeled potential distribution of the zebra mussel (Dreissena polymorpha) in Sweden. Biol Invasions 12:285-296

Hardie DG, Sakamoto K (2006) AMPK: a key sensor of fuel and energy status in skeletal muscle. Physiology 21:48-60

Jost JA, Soltis EN, Moyer MR, Keshwan SS (2015) Linking zebra mussel growth and survival with two cellular stress indicators during chronic temperature stress. Invertebr Biol 134:189-202

Juhel G, Davenport J, O'Halloran J, Culloty SC, O'Riordan RM, James KF, Furey A, Allis O (2006) Impacts of microcystins on the feeding behaviour and energy balance of zebra mussels, Dreissena polymorpha: a bioenergetics approach. Aquat Toxicol 79:391-400

Jurczak T, Tarczyńska M, Izydorczyk K, Mankiewicz J, Zalewski M, Meriluoto J (2005) Elimination of microcystins by water treatment process-examples from Sulejow Reservoir, Poland. Water Res 39:2394-2406
Karatayev AY, Padilla DK, Minchin D, Boltovskoy D, Burlakova LE (2007) Changes in global economies and trade: the potential spread of exotic freshwater bivalves. Biol Invasions 9:161-180

Kaye C, Guy CL (1995) Perspectives of plant cold tolerance: physiology and molecular responses. Sci Prog 78:271-299

Lewandowski K (2001) Development of populations of Dreissena polymorpha (Pall.) in lakes. Folia Malacol 9:171-216

Lowry OH, Rosenbrough NJ, Farr AL, Randal RJ (1951) Protein measurement with Folin phenol reagent. J Biol Chem 193:265-275

Lushchak VI (2011) Environmentally induced oxidative stress in aquatic animals. Aquat Toxicol 101:13-30

Lushchak VI (2012) Glutathione homeostasis and functions: potential targets for medical interventions. J Amino Acids. doi:10.1155/2012/736837

Manduzio H, Rocher B, Durand F, Galap C, Leboulenger F (2005) The point about oxidative stress in molluscs. ISJ 2:91-104

Mates JM (2000) Effects of antioxidant enzymes in the molecular control of reactive oxygen species toxicology. Toxicology 153:83-104

Mazur A, Maier JA, Rock E, Gueux E, Nowacki W, Rayssiguier Y (2007) Magnesium and the inflammatory response: potential physiopathological implications. Arch Biochem Biophys 458:48-56

McMahon RF (1991) Mollusca: Bivalvia. In: Thorp JH, Covich AP (eds) Ecology and classification of North American freshwater invertebrates. Academic Press Inc, Orlando, pp 315-399

McMahon RF (1996) The physiological ecology of the zebra mussel, Dreissena polymorpha, in North America and Europe. Am Zool 36:339-363

Meriluoto J, Codd G (2005) TOXIC. Cyanobacterial monitoring and cyanotoxin analysis. Åbo: Åbo Akademi University Press. Acta Academiae Aboensis. Ser. B, Mathematica et physica, vol 65, pp 1-164

Metcalfe NB, Alonso-Alvarez C (2010) Oxidative stress as a life-history constraint: the role of reactive oxygen species in shaping phenotypes from conception to death. Funct Ecol 24:984-996

Nalepa TF, Schloesser DW (2014) Quagga and zebra mussels: biology, impacts, and control. CRC Press/Taylor \& Francis Group, Boca Raton

Niki E (2008) Lipid peroxidation products as oxidative stress biomarkers. BioFactors 34:171-180

Osman AM, van den Heuvel H, van Noort PCM (2007) Differential responses of biomarkers in tissues of a freshwater mussel, Dreissena polymorpha, to the exposure of sediment extracts with different levels of contamination. J Appl Toxicol 27:51-59

Padilla DK (2005) The potential of zebra mussels as a model for invasion ecology. Am Malacol Bull 20:123-131

Peuthert A, Wiegand C (2004) Glutathione involvement in the biotransformation of microcystins in Dreissena polymorpha. In: Poster abstract, 6th International Conference on Toxic Cyanobacteria (ICTC) 21-27 June, Bergen, Norway

Pflugmacher S, Wiegand C, Oberemm A, Beattie KA, Krause E, Codd GA, Steinberg CEW (1998) Identification of an enzymatically formed glutathione conjugate of the 
cyanobacterial hepatotoxin microcystin-LR: the first step of detoxication. Biochim Biophys Acta 1425:527-533

Pires DLM, Karlsson KM, Meriluoto JAO, Kardinaal E, Visser PM, Siewertsen K, Van Donk E, Ibelings BW (2004) Assimilation and depuration of microcystin-LR by the zebra mussel, Dreissena polymorpha. Aquat Toxicol 69:385-396

Ramcharan CW, Padilla DK, Dodson SI (1992) Models to predict potential occurrence and density of the zebra mussel, Dreissena polymorpha. Can J Fish Aquat Sci 49:2611-2620

Ray PD, Huang B-W, Tsuji Y (2012) Reactive oxygen species (ROS) homeostasis and redox regulation in cellular signaling. Cell Signal 24:981-990

Rice-Evans CA, Diplock AT, Symons MCR (1991) Techniques in free radicals research. In: Burdon RH, van Knippenberg $\mathrm{PH}$ (eds) Laboratory techniques in biochemistry and molecular biology. Elsevier, Amsterdam, pp 147-149

Senft AP, Dalton TP, Shertzer HG (2000) Determining glutathione and glutathione disulfide using the fluorescence probe o-phthalaldehyde. Anal Biochem 280:80-86

Stańczykowska A (1977) Ecology of Dreissena polymorpha (Pall.) (Bivalvia) in lakes. Pol Arch Hydrobiol 24:461-530

Stocks R, Dormandy TL (1971) The autooxidation of human red cell lipids induced by hydrogen peroxide. Br J Haematol 20:95-111

Tarczyńska M, Romanowska-Duda Z, Jurczak T, Zalewski M (2001) Toxic cyanobacterial blooms in drinking water reservoir-causes, consequences and management strategy. Water Sci Technol Water Supply 1:237-246

Valavanidis A, Vlahogianni T, Dassenakis M, Scoullos M (2006) Molecular biomarkers of oxidative stress in aquatic organisms in relation to toxic environmental pollutants. Ecotoxicol Environ Saf 64:178-189

Vanderploeg HA, Liebig JR, Carmichael WW, Agy MA, Johengen TH, Fahnenstiel GL, Nalepa TF (2001) Zebra mussel (Dreissena polymorpha) selective filtration promoted toxic Microcystis blooms in Saginaw Bay (Lake Huron) and Lake Erie. Can J Fish Aquat Sci 58:1208-1221

Viarengo A, Canesi L, Pertica M, Livingstone DR (1991) Seasonal variations in the antioxidant defence systems and peroxidation of the digestive gland of mussels. Comp Biochem Physiol C 100:187-190

Vinogradov GA, Smirnova NF, Sokolov VA, Bruznitsky AA (1993) Influence of chemical composition of the water on the mollusk Dreissena polymorpha. In: Nalepa TF, Schloesser DW (eds) Zebra Mussels: biology, impacts, and control. Lewis Publishers, Boca Raton

Wagner I, Izydorczyk K, Kiedrzynska E, Mankiewicz-Boczek J, Jurczak T, Bednarek A, Wojtal-Frankiewicz A, Frankiewicz P, Ratajski S, Kaczkowski Z, Zalewski M (2009) Ecohydrological system solution for enhancement of ecosystem services: the Pilica river demonstration project. Ecohydrol Hydrobiol 9:13-39

Wenning RJ, Di Giulio RT, Gallaghe EP (1988) Oxidant mediated biochemical effects of paraquat on the ribbed mussel, Geukensia demissa. Aquat Toxicol 12:157-170

Whittier TR, Ringold PL, Herlihy AT, Pierson SM (2008) A calcium-based invasion risk assessment for zebra and quagga mussels (Dreissena spp). Front Ecol Environ 6:180-184

Wiegand C, Pflugmacher S (2005) Ecotoxicological effects of selected cyanobacterial secondary metabolites a short review. Toxicol Appl Pharmacol 203:201-218

Wojtal-Frankiewicz A, Frankiewicz P (2011) The impact of pelagic (Daphnia longispina) and benthic (Dreissena polymorpha) filter feeders on chlorophyll and nutrient concentration. Limnologica 41:191-200

Wojtal-Frankiewicz A, Bernasińska J, Jurczak T, Gwoździński K, Frankiewicz P, Wielanek M (2013) Microcystin assimilation and detoxification by Daphnia spp. in two ecosystems of different cyanotoxin concentrations. J Limnol 72:154-171

Wojtal-Frankiewicz A, Bernasińska J, Frankiewicz P, Gwoździński K, Jurczak T (2014) Response of Daphnia's antioxidant system to spatial heterogeneity in cyanobacteria concentrations in lowland reservoir. PLOS ONE 9(11):e112597

Yang Y, Wu Z, Chen Y, Qiao J, Gao M, Yuan J, Nie W, Guo Y (2006) Magnesium deficiency enhances hydrogen peroxide production and oxidative damage in chick embryo Hepatocyte in vitro. Biometals 19:71-81

Zegura B, Lah TT, Filipic M (2004) The role of reactive oxygen species in microcystin-LR-induced DNA damage. Toxicology 200:59-68

Zhang H, Culver DA, Boegman L (2011) Dreissenids in Lake Erie: an algal filter or a fertilizer? Aquat Invasions 6:175-194 